\title{
Microscopic characterization of silica-rich agrowastes to be used in cement binders: bamboo and sugarcane leaves
}

\author{
Josefa Roselló (1), Lourdes Soriano (2), M. Pilar Santamarina (3), Jorge L. Akasaki (4), José Luiz
} P. Melges (5), Jordi Payá (6)

(1) Departamento de Ecosistemas Agroforestales, Universitat Politècnica de Valéncia, Spain - e-mail: jrosello@upvnet.upv.es

(2) Instituto de Ciencia y Tecnología del Hormigón ICITECH, Universitat Politècnica de Valéncia, Spain -e-mail: lousomar@upvnet.upv.es

(3) Departamento de Ecosistemas Agroforestales, Universitat Politècnica de Valéncia, Spain - e-mail:mpsantam@eaf.upv.es

(4) Departamento de Engenharia Civil, Universidade Estadual Paulista - UNESP - Campus de Ilha Solteira, Brasil -e-mail: akasaki@dec.feis.unesp.br

(5) Departamento de Engenharia Civil, Universidade Estadual Paulista - UNESP - Campus de Ilha Solteira, Brasil - e-mail: jlmelges@dec.feis.unesp.br

(6) Instituto de Ciencia y Tecnología del Hormigón ICITECH, Universitat Politècnica de Valéncia, Spain - e-mail: jjpaya@cst.upv.es

Corresponding author: Jordi Payá (ijpaya@cst.upv.es)

\begin{abstract}
Agrowastes are being produced worldwide in huge quantities and they contain interesting elements for producing inorganic cementing binders, especially silicon. Conversion of agrowastes into ashes is an interesting way of yielding raw material used in the manufacturing of low- $\mathrm{CO}_{2}$ binders. Silica-rich ashes are preferred for preparing inorganic binders. Sugarcane leaves (Saccharum officinarum, SL) and bamboo leaves (Bambusa vulgaris, BvL and Bambusa gigantea, BgL) and their corresponding ashes (SLA, BvLA and BgLA) were chosen as case studies. These samples have been analysed by means of optical microscopy (OM), CRYO-SEM, SEM and FESEM. Spodograms have been obtained for BvLA and BgLA, which have high proportions of silicon, but no spodogram was obtained for SLA because of the low silicon content. Different types of phytoliths (specific cells, reservoirs of silica in plants) in the studied leaves have been observed. These phytoliths maintained their form after calcination at temperatures in the 350$850^{\circ} \mathrm{C}$ range. Due to the chemical composition of these ashes, they are of interest for use in cements and concrete, because of their possible pozzolanic reactivity. However, the presence of significant amounts of $\mathrm{K}$ and $\mathrm{Cl}$ in the prepared ashes implies a limitation of their applications.
\end{abstract}

Keywords: agrowaste; silica; phytolith; microscopy; pozzolan; spodogram 


\section{Introduction}

At present, the generation and management of waste is an issue of vital importance for economic and environmental development, and has direct implications for sustainability in the XXI century. Valorization of wastes consists of converting them for producing energy, fuels, chemicals and other useful products. Valorization puts the emphasis on environmental indicators and sustainability goals (Nzihou, 2010). Of all the wastes generated, those that occupy the greatest volume are related to primary activities, specifically farming and forestry. The recovery of such waste is focused in certain cases on the preparation of agricultural feed for livestock. Also, many recent studies have assessed the great potential for applying specific crops to chemical production (Tuck et al., 2012).

Because of the volume of crops produced worldwide, strategies focused on high-consumption practices may be developed. In this sense, the construction sector is of great interest because it is the human activity in which the most tons of materials are processed. Thus, interesting approaches for producing vegetable fibres as non-conventional reinforcement for construction materials (cement- or polymer-based) are being developed (Santos et al., 2015). However, only a small part of biomass can be converted into useful fibres; in other cases, valorization in alternative sectors is not possible because the presence of some elements in the biomass or the transport distances do not permit viable technical solutions.

In that case (Payá et al., 2010), it is possible to carry out a first valorization (first stage, Figure 1) through the recovery of energy by combustion processes in which a secondary material, the ash residue, is generated. Ashes can be valued at a later stage (second stage, Figure 1): depending on the chosen option, different valorization levels can be achieved. The lowest valorization level corresponds to landfill (no recovery); the highest levels correspond to the use of these ashes as mineral additions for manufacturing cement and concrete. In some cases, the ash obtained is rich in silicon, which is of crucial interest in the field of high performance concrete: amorphous silica $\left(\mathrm{SiO}_{2}\right)$ has pozzolanic properties, i.e. the capacity for chemical combination with portlandite released in the hydration of Portland cement to form cementitious materials of insoluble character (Mehta, 1989). These ashes could compete with microsilica, a byproduct from the silicon and ferrosilicon alloy industries, which has become a high-added value mineral addition in the concrete sector: this microsilica is very expensive and its production is limited to only a few countries. Thus, the production of highreactive pozzolans from biomass is an interesting issue for many countries, mainly for developing ones. 
Figure 1: Valorization steps and levels for agrowaste.

Plants absorb silicon from the soil as silicic acid and also deposited as amorphous hydrated silica or opal $\left(\mathrm{SiO}_{2} \cdot \mathrm{nH}_{2} \mathrm{O}\right)$ in the cell wall, inside the cells (intracellular spaces or cell lumen) and in the intercellular spaces of different plant organs such as leaves, pods, stems, inflorescences (i.e. herringbones) and epidermal appendages (trichomes) (Prychid et al., 2003).

The silica content is between 0.1 and $10 \%$ dry weight of higher plants. In general, monocots accumulate more silica than dicots, although there may be differences even to genus level (Ma \& Yamaji, 2006). Among monocots, the Poaceae family (grasses) accumulate much more silica in the cellular tissues than other families of plants.

Different siliceous structures have been found in plants. There are special siliceous cells that are called phytoliths or silico-phytoliths. After the death of the plant, these phytoliths are preserved in the soil for hundreds or thousands of years and can therefore be used to understand the inter-relationships that occurred between plants, ecosystems and ancient human communities. Additionally, these siliceous structures occluded some organic carbon when formed during the plant growth and play an important role in the long-term carbon sink of ecosystems (Li et al., 2014).

Silicon has an important role in plant-environment relationships, and confers resistance and protection against various biotic and abiotic environmental factors. The accumulation of silica provides mechanical stability to the tissues, reduces water loss through transpiration (resistance to water stress), reduces the problems caused by lack or excess of nutrients, and protects the plant against attack by insects and microorganisms, thereby reducing infections caused by them (Epstein, 1999).

A wide variety of phytolith shapes can be found (Erra et al., 2011) and usually most of them are less than 50 micrometers in size. Their shape depends on the plant tissue in which the silica was deposited and the intracellular space thereof. The most characteristic phytoliths have the following morphotypes: dumbbell, saddle and cross. In the case of extracellular deposits, in external plant tissues (epidermis), trichomes are the most typical.

The epidermis of Poaceae family plants has taxonomic value, and therefore the most important cellular elements are used as diagnostic characteristics: silica cells (phytoliths), cork cells and trichomes (bicellular, unicellular, papillose). These elements have structural value and their presence and distribution permit the classification of plants in 
differentiated sub-families. There are different classifications of siliceous bodies, and three different dermotypes in grasses can be distinguished (Figure 2) according to Prat (1936).

a) Panicoide dermotype: characterized by bilobated silica cells (dumbbell shape) and bicellular trichomes in different forms (e.g. sugarcane); b) Festucoide dermotype: rounded or elongated silica cells with slightly wavy walls, trichomes, if present, are unicellular (e.g. festuca, hay); and c) Bambusoide dermotype: silica cells of various shapes (dumbbell and saddle) and unicellular (prickle) and bicellular (filiformed) trichomes (e.g. bamboo and guadua).

Few studies have been performed on the chemical composition of phytoliths. Kamenik et al. (2013) studied phytoliths from barley (festucoid type), and they found a silica content of $84.8 \%$ for phytoliths in the leaf and $89.8 \%$ for those present in the stem.

Figure 2. Dermotypes found in leaves of Poaceae family plants (ph: phytolith; st: stoma; tr: trichome).

The presence of silica in agrowaste and then in the ashes produced by its combustion is of great interest for several fields including ceramics (Mohapatra et al., 2011; Teixeira et al., 2014) and nanotechnology (Neethirajan et al., 2009). However, the most important field for utilizing this type of ash is the cement and concrete industry. Research on the use of ash from agricultural waste has been increasing in recent years (Hosseini et al., 2011) in the manufacture of cement (biocements). Rice husk ash has been the most studied (Aprianti et al., 2015) waste: its chemical composition reveals that the silica content is the major compound, in excess of 92-93\% by weight based on ignited samples (without carbon or organic matter) (Payá et al., 2010). In other cases, the $\mathrm{SiO}_{2}$ content in the ash is lower. For example, a large amount of silica has been found (Hosseini et al., 2011) in ashes from sugarcane straw (59\%), sawdust (67\%), corncob (66\%), oil palm shell (63\%), wheat straw (54\%) and bamboo leaf (76\%).

Many of these ashes were tested (Aprianti et al., 2015) from the viewpoint of reactivity with Portland cement and/or hydrated lime, and their pozzolanic activity has been determined by means of mechanical tests and/or physico-chemical tests (thermogravimetry, electrical conductivity, X-ray diffraction, microscopy, etc.). Furthermore, in some cases the durability properties of concretes containing biomass ashes have been assessed. In cement chemistry, it is crucial to know the nature of individual particles in order to study their reactivity (e.g.: hydration process and/or pozzolanic reaction process). This is due to the reactions involve a heterogeneous system (liquid/solid, e.g.: water/cement+pozzolan), and each individual particle could produce specific reaction compounds. 
The aim of this research is to study in depth from the microscopic point of view the plant structures and the ashes obtained from bamboo leaves and sugarcane leaves, in order to analyse the silica distribution and the presence of other compounds, and also the presence of silica bodies (phytoliths). Thus, selected information about the chemical nature of ashes will be obtained, interesting for further studies in Portland cement blends (ashes acting as pozzolans). Both bamboo and sugarcane leaves are residues from several industries. Specifically, bamboo leaves are produced in huge amounts because this is probably the fastest-growing and highest yielding natural resource and construction material available to mankind (Asha et al., 2014). The use of bamboo cane and its fibres generates solid waste (mainly leaves and short stems). The same occurs in sugarcane harvesting. The burning of this biomass in open landfills (Le Blond et al., 2008) has a negative impact from the environmental point of view, producing smoke and very dangerous airborne particles.

\section{Methods and Materials}

Leaf samples of bamboo (Bambusa vulgaris, BvL and Bambusa gigantea, BgL) and sugarcane (Saccharum officinarum, SL) were collected in Ilha Solteira (São Paulo, Brazil). Old leaves were taken from the plant, because silicon is an element accumulated along the life of the plant, and it is not moved to other parts of the plant once is deposited as silica (Ma \& Yamaji, 2006). To correctly identify structures rich in silica (phytoliths) and their location within the plant, studies on both collected material (fresh and dried) and ash resulting from combustion in a muffle furnace at selected temperatures were performed. Leaves were previously washed with deionized water. Small pieces of the leaves were cut from the center part.

Preparation of samples was carried out depending on the type of study.

For fresh material studies, leaf samples of bamboo and sugarcane were washed thoroughly to remove residual soil contamination. Sections were cut into one squared centimeter, and paradermal lamellae of 40 microns thick were prepared using a freezing microtome (Jung AG). Subsequently these cuts were clarified with a solution of 50\% sodium hypochlorite and washed several times with distilled water.

For dried material studies, small samples of leaves were dried at $105{ }^{\circ} \mathrm{C}$ for 24 hours in a laboratory oven (Memmert UN model).

And for calcined material (ash) studies, the fresh samples were calcined for 1 hour at the selected temperature (350, 450, 550 and $850{ }^{\circ} \mathrm{C}$; these temperatures were selected in terms of stability of the spodogram) in a muffle furnace 
(Carbolite RHF model 1500). The obtained ashes were: bamboo leaf ash (from Bambussa vulgaris BvLA; from Bambussa gigantea BgLA) and sugarcane leaf ash (SLA).

Optical microscopy (OM): the cuts of fresh material, once clarified, were stained with safranin-light green, dehydrated and mounted using a synthetic mix of resins (Eukit, Mounting medium for microscope preparation), for observation under a light microscope (Olympus PM-10AK3).

Cryo-SEM microscopy: clarified cuts (fresh material) were frozen in liquid nitrogen and were transferred to a Cryotransfer system (CT-1000C) interconnected with a scanning electron microscope (JEOL JSM-5410). The sample was sublimed at $-90{ }^{\circ} \mathrm{C}$ and once coated with gold the structure was analysed by scanning electron microscopy (SEM).

Scanning electron microscopy (SEM): selected samples (dried leaves and ashes) were coated with carbon (Baltec SCD 005 evaporation supply CEA) and then analysed with a scanning electron microscope (JEOL-JSM-6300) equipped with energy dispersive X-ray (EDX) for microanalysis. Because the sample is formed by interconnected particles, is highly porous and non polished surface was prepared, EDX analyses must be considered from the semiquantitative point of view.

Field emission scanning electron microscopy (FESEM): Samples were studied by using a ZEISS ULTRA 55 microscope. Samples for taking images were studied at $20 \mathrm{kV}$ and covered with gold. Samples for chemical analysis (EDX) were not covered and studied at $15 \mathrm{kV}$.

\section{Results and discussion}

\section{Bamboo leaf and bamboo leaf ash}

In the optical microscopy images (Figures 3a and 3b), siliceous bodies (phytoliths) in BvL were identified in alignment. Two phytolith shapes were observed: the larger ones "saddle” and the smaller ones "dumbbell”. The major axis of the phytoliths was perpendicular to the longitudinal axis of the leaf. In Figure 3c, the arrangement of the saddle phytoliths was clearly seen by the Cryo-SEM technique, although no evidence of dumbbell phytoliths was found. A bamboo BvL leaf dried at $105{ }^{\circ} \mathrm{C}$ (Figure 3d) was studied by SEM: in this case, the relative positions of both phytolith types were 
also observed. The EDX analysis (in atomic percentage) of the sample (carbon was not taken in this analysis) revealed a high proportion of Si and O (30.46 and 63.34\% respectively), but also important was the presence of three chemical elements: Ca (0.55\%), K (3.74\%) and $\mathrm{Cl}(1.91 \%)$. The presence of chloride and potassium is indicative of the presence of significant amounts of potassium chloride $(\mathrm{KCl})$, probably originally accumulated in intracellular and extracellular fluids. These minerals, when drying, were deposited on the organic matter surface.

Figure 3. Images for bamboo leaf (BvL): a) optical microscopy (x40); b) an enlarged zone of previous image; c) cryoSEM image for fresh leaf; d) SEM image for dried leaf at $105^{\circ} \mathrm{C}$. (Key- d: dumbbell phytolith; s: saddle phytolith).

FESEM studies were carried out on BgL samples dried at $105^{\circ} \mathrm{C}$. Selected micrographs are shown in Figure 4 . They show the lower leaf surface (abaxial surface). The upper leaf surface (adaxial surface) was very homogeneous and it was very difficult to distinguish any structure because of the organic matter coating. In Figure 4a, a general view of the abaxial surface and aligned saddle phytoliths are distinguished. Figure 4b shows an image enlargement, in which dumbbell phytoliths are aligned together with “saddles”, close to trichomes.

Bamboo leaves were calcined at different temperatures and the resulting ashes were analysed by SEM (at 550 and $850^{\circ} \mathrm{C}$, Figure 5 for BvLA) and FESEM (450 and $650^{\circ} \mathrm{C}$, Figure 6 for BgLA). After treating at $550^{\circ} \mathrm{C}$, the spodogram (structural residue resulting from the removal of organic matter by burning, maintaining the leaf's structure) was clearly observed (Figure 5a, abaxial surface). The same type of arrangement as that found by means of optical microscopy was confirmed. Phytoliths of the two types were in a continuous matrix of an inorganic nature which results from the presence of silica and other minerals in the cell walls of the leaf. In this case, after removal of the organic matter, the chemical composition determined by EDX was: Si (23.33\%), O (58.13\%), K (11.77\%) and Cl (3.40\%). This means that after calcination at $550^{\circ} \mathrm{C}$, potassium and chloride remained on the surface of the silica skeleton. Other minor components were also quantified: Ca (1.22\%), P (0.84\%), S (0.43\%) and Mg (0.52\%). Elemental analysis of saddle phytoliths (Figure 5b) demonstrated their siliceous nature: Si (31.20\%), O (64.18\%), S (0.07\%), Cl (1.38\%) and K (3.18\%). 
Figure 4. FESEM micrographs for BvL dried at $105^{\circ} \mathrm{C}$ : a) general view of the abaxial surface; b) enlarged zone (Key: s: saddle; d: dumbbell; tr: trichome).

Figure 5. SEM micrographs for bamboo leaf ashes (BvLA): a) calcined at $550^{\circ} \mathrm{C}$; b) saddle phytolith at $550^{\circ} \mathrm{C}$; c) at $850^{\circ} \mathrm{C}$; d) at $850^{\circ} \mathrm{C}$, selected spots (A: matrix; B: saddle phytolith; C: dumbbell phytolith) for chemical composition analysis (given in Table 1). (Key- d: dumbbell phytolith; s: saddle phytolith)

The sample calcined at $850^{\circ} \mathrm{C}$ (Figure 5c) still shows the spodogram, although in this case the inorganic material is morphologically affected. The phytoliths remain nearly in their original position. The chemical composition for the overall sample is given in Table 1. From the chemical point of view, the EDX analysis comparison of samples treated at 550 and $850^{\circ} \mathrm{C}$ revealed that $\mathrm{Si}$ and $\mathrm{O}$ are the main elements, confirming the siliceous nature of the ash. However, significant differences were found in $\mathrm{K}$ and $\mathrm{Cl}$ content: for the sample calcined at $550^{\circ} \mathrm{C}$ the atomic percentages for these chemical elements were 11.77 and $3.40 \%$ respectively, whereas for the sample at $850^{\circ} \mathrm{C}$ they were 1.77 and $0.04 \%$. This leads to the conclusion that the temperature of $850^{\circ} \mathrm{C}$ produced a volatilization of potassium chloride (its melting point is $776^{\circ} \mathrm{C}$ ). The chemical composition of BvLA was not homogeneous, as can be seen in Figure $5 \mathrm{~d}$ and in Table 1: Ca, P, S, and Mg were mainly concentrated in the matrix (Figure 5d, spot A) that surrounded the phytoliths, having higher percentages of these elements than those found for the overall sample. Also K had the highest percentage for matrix (2.14\%) which was higher than for the overall sample (1.77\%), for saddle phytoliths (Figure 5d, spot B) and dumbbell phytoliths (Figure 5d, spot C). Chloride was found to be negligible in all the selected analysis spots.

Table 1. Chemical compositions (EDX, atomic percentage, \%) for bamboo leaf calcined at $850^{\circ} \mathrm{C}$ (BvLA) (spots identified in Figure 5d).

Some chemical analyses have been reported for BLA (Dwivedi et al., 2006; Singh et al., 2007; Villar-Cociña et al., 2011; Frías et al., 2012; Iorliam et al., 2012; Asha et al., 2014). In them, silicon dioxide was the major compound (see Table 2), and a similar percentage of $\mathrm{SiO}_{2}$ was found for the overall analysis in this work. The lowest $\mathrm{SiO}_{2}$ data (Iorliam et al., 2012; Asha et al., 2014) were found for samples with a high loss on ignition parameter (this LOI showed that the 
calcinations were far from completed). However, no data on the chloride percentage was supplied in any previous report. Yet this fact is important for the application of this type of ash in the manufacture of cements and concretes: chloride content should be taken into account in order to assess the possible reinforcement corrosion.

According to the data presented in Table 1, it is evident that there is a wide variety of structures with different chemical compositions, undoubtedly attributed to the differentiated tissues and cells. Thus, in order to make an overall analysis by means of EDX measurements, chemical compositions were taken from 16 tests on BgLA calcined at $850^{\circ} \mathrm{C}$. The analysis was carried out by analysing a $115 \mu \mathrm{mx} 85 \mu \mathrm{m}$ area: from the 16 tests, mean values and their standard deviations were measured (see Table 3). It is confirmed that volatilization of chlorides took place due to the high calcination

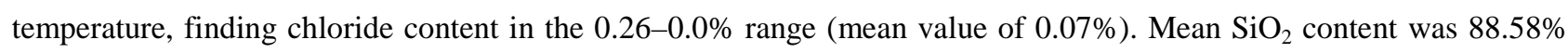
which was very similar to that found in BvLA. In a few tests, small amounts of $\mathrm{Al}_{2} \mathrm{O}_{3}$ and $\mathrm{Fe}_{2} \mathrm{O}_{3}$ were identified, which was attributed to the presence of soil particles adhered to the leaves.

Table 2. Reported chemical composition for bamboo leaf ashes and BvLA (this work).

Table 3. Mean values of chemical composition for BgLA calcined at $850^{\circ} \mathrm{C}$. Values were calculated from EDX analysis on $115 \mu \mathrm{mx} 85 \mu \mathrm{m}$ zone (16 tests were carried out).

In Figure 6 the spodogram of the adaxial surface for BgLA $\left(650^{\circ} \mathrm{C}\right)$ is observed. In this part of the calcined leaf, only dumbbell phytoliths were identified, surrounded by a smoother silica matrix. This matrix was very porous, indicating that the silica content in most of the cellules was lower than that found in the phytolitic specialized single cells. By contrast, the abaxial surface (Figure 7) showed another arrangement: saddle and dumbbell phytoliths are aligned, surrounded by rough silica matrix, in which two types of trichomes (prickle hairs, filiformed hairs) are identified (Motomura et al., 2006).

Figure 6. FESEM micrographs of adaxial surface for BvLA calcined at $650^{\circ} \mathrm{C}$. 
Figure 7. FESEM micrographs of abaxial surface for BvLA calcined at $650^{\circ} \mathrm{C}$ (Key- p: prickle hairs; f: filiformed hairs; d: dumbbell phytolith; s: saddle phytolith).

Phytoliths were better observed on samples calcined at $850^{\circ} \mathrm{C}$. FESEM micrographs for BgLA are shown in Figure 8 . The saddle and dumbbell phytoliths in BvLA were similar to those found in BgLA. Saddle phytoliths were 16-20 $\mu \mathrm{m}$ long and 9-12 $\mu \mathrm{m}$ wide, whereas dumbbell phytoliths were 10-15 $\mu \mathrm{m}$ long and 6-7 $\mu \mathrm{m}$ wide.

Figure 8. FESEM micrographs for BgLA at $850^{\circ} \mathrm{C}$ : a) dumbbell phytoliths; b) dumbbell (d) and saddle (s) phytoliths.

\section{Sugarcane leaves and sugarcane leaf ashes.}

In Figure 9, several images of sugarcane leaf (SL) are shown. In Figure 9a, under optical microscopy, the general arrangement of the cellular elements of the epidermis is observed. Dumbbell type phytoliths are aligned and arranged so that the major axis thereof is parallel to the major axis of the epidermal cells. Figure 9b shows an enlarged image in which some dark inclusions in the phytoliths are identified, probably related to the carbon sink mentioned previously [8]. Figures 9c and 9d show these inclusions and also the variability of shapes for dumbbell phytoliths (Gallego \& Distel, 2004): the phytolith in Figure 9c shows a short shank-convex end, and the phytolith in Figure 9d shows a short shank-straight end. The cross-section of SL is observed in Figures 9e and 9f. It can be seen that the phytolith is situated on the vascular bundles (Motomura et al., 2006) and the phytolith section was a trapezoid-like shape.

Figure 9. Optical microscope images for sugarcane leaves: a-d) paradermal sections; e-f) transversal sections (d: dumbbell phytolith; st: stoma; tr: trichoma; vb: vascular bundles). Magnification: a) x20; b) x40; c) x100; d) x100; e) $\mathrm{x} 40$; $\mathrm{f}) \mathrm{x} 100$. 
Figure 10. Cryo-SEM micrographs for sugarcane leaf: a and b) cross-section; c and d) abaxial surface (Key- d: dumbbell phytolith; st: stoma; vb: vascular bundle).

Cryo-SEM images (Figure 10) were taken to identify the disposition of phytoliths in sugarcane leaf. Figure 10a shows a cross-section of the leaf, in which a phytolith in the abaxial surface was situated in a similar position to those found in Figures 9e and 9f, among the epidermis cells and on the vascular bundle. Figure 10b shows an enlargement image of the selected zone: a trapezoidal shape was observed for the phytolith. Interesting detail of the panicoide dermotype is identified in Figure 10c. The chemical composition determined by EDX has a lower proportion of Si (5.18\%) compared to O (88.10\%); moreover, the presence was found of other chemical elements in relevant quantities, such as $\mathrm{Cl}$ (3.15\%), $\mathrm{K}(2.90 \%), \mathrm{Mg}(0.26 \%), \mathrm{P}(0.18 \%)$ and S (0.23\%). It can be noticed that the inorganic residue was very different from the case of bamboo leaf: for SL, the silica skeleton was under the organic coating and the amount of phytoliths was lower, and consequently the relative proportion of silicon was reduced. Finally, Figure 10d clearly shows phytoliths of the dumbbell type which appeared in the surface of the leaf.

FESEM studies on SL dried at $105^{\circ} \mathrm{C}$ showed that the adaxial surface did not present any identifiable phytoliths. However, in the abaxial surface there were silica cells (Figure 11a). It was possible to identify different morphologies for dumbbell phytoliths (Figures 11b-d) and their length/wide ratio varied significantly.

Figure 11. Micrographs of sugarcane leaf (SL) dried at $105^{\circ} \mathrm{C}$ : a and b) FESEM; c and d) SEM.

Calcination of sugarcane leaves generates sugarcane leaf ash (SLA), in which the resulting material tends to be completely disordered, as can be seen in Figure 12: the cellular leaf structure tissues (spodogram) are not maintained when organic matter is removed by combustion. In Figure 12 two SEM micrographs of SLA obtained at $450^{\circ} \mathrm{C}$ reflected this behaviour. In the first one (Figure 12a), a lot of small particles of irregular shapes and some cellular structures still maintaining their original structure (stomata and phytoliths) were observed. In Figure 12b, a dumbbell phytolith was surrounded by irregular particles. The chemical composition of the ash revealed again the low proportion of silicon 
compared to other chemical elements: Si (5.24\%), O (72.14\%), Mg (4.53\%), Cl (2.61\%), K (8.81\%), P (2.37\%), S (0.85\%) and Ca (3.25\%). Probably the low Si content, and that of silica, makes it impossible to maintain the spodogram after calcination. In Figure 12b a detail of a dumbbell phytolith is shown: its chemical composition was very rich in silica: Si (25.89\%), O (71.13\%), Cl (0.19\%), K (2.61\%), Mg (0.12\%) and S (0.06\%). This means that a significant proportion of silica in the ash is concentrated in phytoliths remaining after calcination.

Figure 12. Micrographs for SLA calcined at $450^{\circ} \mathrm{C}$ : a) SEM general view with D spot and E zone; b) detail of dumbbell phytolith; c) SEM general view with F and G spots and H zone ; d) FESEM general view. Chemical compositions from spots and zones are given in Table 4.

On the micrographs shown in Figures 12a and 12c, selected chemical analyses (spots and zones) were obtained by EDX. In Figure 13 these spots and zones are marked and the corresponding chemical analysis is summarized in Table 4. As occurs for bamboo ashes, a wide range of chemical composition was found depending on the spot/zone selected. Analysis of the phytoliths yielded the highest Si content (spots D and G), whereas $\mathrm{K}, \mathrm{Cl}, \mathrm{Ca}, \mathrm{Mg}, \mathrm{P}$ and S contents were significantly lower than those found for the other zones/spots. In order to analyse in depth the chemical composition of SLA by means of EDX tests, 14 tests on SLA obtained at $650^{\circ} \mathrm{C}$ were taken. Analyses were carried out on a $115 \mu \mathrm{mx} 85 \mu \mathrm{m}$ area: from the 14 tests, mean values and their standard deviations were measured (see $\mathrm{Table} 5$ ). SiO $_{2}$ and $\mathrm{K}_{2} \mathrm{O}$ are the major compounds in the ash: the presence of a high percentage of potassium could be a problem when the ash is added to concrete mix because of the alkali-silica reaction: it is well-known (Diamond, 1975), that the presence of alkalis in the Portland cement matrix could produce an expansive reaction when reacted towards specific types of aggregates. Opal aggregates react with alkalis to form expansive sodium silicate gel (N-S-H) in the aggregate-matrix interface (Diamond, 1976). Thus, some adjustments may need to be taken into account when these sugarcane leaf ashes replace Portland cement in concrete if reactive aggregates are used. The obtained chemical compositions in this work were very different from those reported previously, as can be seen in Table 6. The reported values were probably taken from samples of a mixture of leaves, straw, sugarcane and soil, and consequently a higher silica proportion was obtained. Additionally, percentages of $\mathrm{Al}_{2} \mathrm{O}_{3}$ and $\mathrm{Fe}_{2} \mathrm{O}_{3}$ in reported data (Frías et al., 2007; Singh et al., 2009; Le Blond et al., 2010; Guzmán et al., 2011; Arumugam et al., 2012; Rodrigues et al., 2013) were very high due to the soil contamination of the leaves/straw, unlike the very low values for these oxides in the studied ash in this work, which were below $0.5 \%$ because the calcined leaves were previously washed with deionized water. 
Table 4. Chemical compositions (EDX, atomic percentage, \%) for sugarcane leaf ash (SLA) calcined at $450^{\circ} \mathrm{C}$ (spots and zones identified in Figure 13).

Table 5. Mean values of chemical composition for SLA calcined at $450^{\circ} \mathrm{C}$. Values were calculated from EDX analysis on $115 \mu \mathrm{mx} 85 \mu \mathrm{m}$ zone (14 tests were carried out).

Table 6. Reported chemical composition for sugarcane leaf ashes and SLA (this work).

In order to maintain the skeleton of the tissues, sugarcane leaf was calcined at $350^{\circ} \mathrm{C}$. At this temperature the organic matter was not completely removed, so the residual organics and/or carbon together with the silica helped to maintain the original structure of the cells. In Figure 13, FESEM micrographs of the obtained material are shown. In the adaxial surface, no evidence of the presence of phytoliths is obtained (Figure 13a), whereas for the abaxial surface (Figure 13b) phytoliths were arranged according to the observations at $105^{\circ} \mathrm{C}$.

Figure 13. FESEM micrographs for SLA calcined at $350^{\circ} \mathrm{C}$ : a) adaxial surface; b) abaxial surface. (Key- d: dumbbell phytolith). 
In Figure 14, a complete arrangement of the phytoliths is observed after calcinations at $350^{\circ} \mathrm{C}$. In this case, because part of the organic matter was removed, the identification of these silica structures was easier than for the sample dried at $105^{\circ} \mathrm{C}$.

Figure 14. FESEM micrographs of abaxial surface for SLA calcined at $350^{\circ} \mathrm{C}$.

\section{Conclusions}

Microscopic studies have shown the presence of phytoliths (silica cells) in bamboo leaf (BL) and sugarcane leaf (SL). A higher proportion of silica in the cell walls of bamboo leaf was observed than in sugarcane leaf.

The arrangement and type of phytoliths (dumbbell and saddle) is characteristic of each type of leaf: phytoliths were aligned parallel to the longitudinal axis of the cells for SL (panicoide type) and aligned transversely for BL (bambusoide type).

Bamboo leaf ash (BLA: BvLA from Bambusa vulgaris and BgLA from Bambusa gigantea) presented significant amounts of $\mathrm{K}$ and $\mathrm{Cl}$, and sugarcane leaf ashes (SLA) have important amounts of other chemical elements: Mg, Ca, P and S. A reduction of chloride percentage was observed when ashes were obtained at high temperature $\left(850^{\circ} \mathrm{C}\right)$, due to the volatilization of potassium chloride.

The silica content in the ash is directly related to the formation of the spodogram after calcination. For SLA, which has the lowest silica content, the cell structure practically collapses after calcination. However, a perfect spodogram for BLA was maintained at $850^{\circ} \mathrm{C}$.

The phytoliths characterized in both ashes (BLA and SLA) had a very high content of silica. Other elements were presented in the inorganic matter after calcinations. For BLA, silica was the main compound, while for SLA significant percentages of $\mathrm{K}_{2} \mathrm{O}, \mathrm{Cl}, \mathrm{CaO}, \mathrm{MgO}, \mathrm{P}_{2} \mathrm{O}_{5}$ and $\mathrm{SO}_{3}$ were found. EDX chemical analysis demonstrated that the chemical composition varied depending on the particle or zone analysed. 
These ashes are materials that can be used for the manufacture of cement and concrete, although account must be taken of the presence of $\mathrm{K}$ and $\mathrm{Cl}$, which may limit their applications. Potassium could generate expansive problems by alkali-silica reaction with reactive aggregates, and chloride could lead to corrosion processes in steel-reinforced concrete.

\section{Acknowledgements}

Thanks are given to Conselho Nacional de Desenvolvimento Científico e Tecnológico (Projeto CNPq 40174/2013-1) of Brazil for funding the research. Also, thanks are given to Electron Microscopy Service of the Universitat Politècnica de València and Materials Department of Universidade Estadual Paulista at Ilha Solteira.

\section{References}

APRIANTI, E., SHAFIGH, P., BAHRI, S. \& FARAHANI, J.N. (2015). Supplementary cementitious materials origin from agricultural wastes - A review. Constr. Build. Mater. 74, 176-187.

ARUMUGAM, A., PONNUSAMI, V. \& MODIFIED, S.B.A. (2012). 15 synthetized using sugarcane leaf ash for nickel adsorption. Indian J. Chem. Technol. 20, 101-105.

ASHA, P., SALMAN, A. \& KUMAR, R.A. (2014). Experimental study on concrete with bamboo leaf ash. Int. J. Eng. Adv. Technol. 3, 46-51.

DIAMOND, S. (1075). A review of alkali-silica reaction and expansion mechanisms 1. Alkalis in cements and in concrete pore solutions. Cem. Concr. Res. 5, 329-345.

DIAMOND, S. (1976). A review of alkali-silica reaction and expansion mechanisms 2. Reactive aggregates. Cem. Concr. Res. 6, 549-560.

DWIVEDI, V.N., SINGH, N.P., DAS, S.S. \& SINGH, N.B. (2006). A new pozzolanic material for cement industry: Bamboo leaf ash. Int. J. Phys. Sci. 1, 106-111.

EPSTEIN, E. (1999). Silicon. Annu. Rev. Plant Physiol. Plant Mol. Biol. 50, 641-664. 
ERRA, G., ZUCOL, A.F. \& KRÖHLING, D.M. (2011). Phytolitic analysis of the Tezanos Pinto Formation (Late Pleistocene-early Holocene) in the northwestern sector of its distribution area, Provincia de Entre Ríos (Argentina). Rev. Mex. Cienc. Geol. 28, 398-412.

FRÍAS, M., SAVASTANO, H., VILLAR, E., SÁNCHEZ DE ROJAS, M.I. \& SANTOS, S. (2012). Characterization and properties of blended cement matrices containing activated bamboo leaf wastes. Cem. Concr. Comp. 34, 10191023.

FRÍAS, M., VILLAR-COCIÑA, E. \& VALENCIA-MORALES, E. (2007). Characterisation of sugar cane straw waste as pozzolanic material for construction: Calcining temperature and kinetic parameters. Waste Manage. 27, 533-538.

GALlEGO, L. \& DiSTEL, R.A. (2004). Phytolith Assemblages in Grasses Native to Central Argentina. Ann. Bot. 94, 865-874.

GUZMÁN, A., GUTiÉRreZ, C., AMigÓ, V., DE GUTIÉRREZ, R.M. \& DELVASTO, S. (2011). Pozzolanic evaluation of the sugar cane leaf. Mater. Constr. 61, 213-225.

HOSSEINI, M.M., SHAO, Y. \& WHALEN, J.K. (2011). Biocement production from silicon-rich plant residues: Perspectives and future potential in Canada. Biosystems Eng. 110, 351-362.

IORLIAM, A.Y., AGBEDE, I.O. \& JOEL, M. (2012). Effect of bamboo leaf ash on cement stabilization of Makurdi shale for use as flexible pavement construction material. Am. J. Sci. Ind. Res. 3, 166-174.

KAMENIK, J., MIZERA, J. \& RANDA, Z. (2013). Chemical composition of plant silica phytoliths. Environ. Chem. Lett. 11, 189-195.

LE BLOND, J.S., HORWELL, C.J., WILLIAMSON, B.J. \& OPPENHEIMER, C. (2010). Generation of crystalline silica from sugarcane burning. J. Environ. Monit. 12, 1459-1470.

LE BLOND, J.S., WILliAMSON, B.J., HORWELL, C.J., MONRO, A.K., KIRK, C.A. \& OPPENHEIMER, C. (2008). Production of potentially hazardous respirable silica airborne particulate from the burning of sugarcane. Atmos. Environ. 42, 5558-5568.

LI, B., SONG, Z., WANG, H., LI, Z., JIANG, P. \& ZHOU, G. (2014). Lithological control on phytolith carbon sequestration in mosobamboo forests. Sci Rep 4, art5262 (doi:10.1038/srep05262).

MA, J.F. \& YAMAJI, N. (2006). Silicon uptake and accumulation in higher plants. Trends Plant Sci. 11: $392-397$.

MEHTA, P.K. (1989). Pozzolanic and Cementitious By-Products in Concrete: Another Look. ACI Special Publication pp.1-44. Farmington Hills, MI (USA), American Concrete Institute

MOHAPATRA, S., SAKTHIVEL, R., ROY, G.S., VARMAC, S., SINGH, S.K. \& MISHRA, D.K. (2011). Synthesis of $\beta$-SiC Powder from Bamboo Leaf in a DC Extended Thermal Plasma Reactor. Mater. Manuf. Processes 26, 13621368. 
MOTOMURA, H., FUJII, T. \& SUZUMI, M. (2006). Silica Deposition in Abaxial Epidermis before the Opening of Leaf Blades of Pleioblastus chino (Poaceae, Bambusoideae). Ann. Bot. 97, 513-519.

NEETHIRAJAN, S., GORDON, R. \& WANG, L. (2009). Potential of silica bodies (phytoliths) for nanotechnology. Trends Biotechnol. 27, 461-467.

NZIHOU, A. (2010). Toward the valorization of waste and biomass. Waste Biomass Valorization 1, 3-7.

PAYÁ, J., MONZÓ, J. \& BORRACHERO, M.V. (2010). Outstanding aspects on the use of rice husk ash and similar agrowastes in the preparation of binders. In: Proceedings of the First Pro-Africa conference: Non conventional building materials based on agroindustrial wastes. Pirassununga, São Paulo (Brazil). Savastano Jr H (Ed). pp. 179181, ISSN 2177-6334.

PRAT, H. (1936). La Systematique des Graminées: Ann. Sci. Nat. 18,165-258.

PRYCHID, C.J., RUDALL, P.J. \& GREGORY, M. (2003). Systematics and biology of silica bodies in monocotyledons. Bot. Rev. 69, 377-440.

RODRIGUES, M.S., BERALDO, A.L., SAVASTANO, JR. H. \& SANTOS, S.F. (2013). Sugarcane straw ash as mineral addition in fibercement. Rev. Bras. Eng. Agric. Amb. 17, 1347-1354.

SANTOS, S.F., TONOLI, G.H.D., MEJIA, J.E.B., FIORELLI, J. \& SAVASTANO, Jr. H. (2015). Non-conventional cement-based composites reinforced with vegetable fibers: A review of strategies to improve durability. Mater. Constr. 65:e041.

SINGH, N.B., DASA, S.S., SINGH, N.P. \& DWIVEDI, V.N. (2007). Hydration of bamboo leaf ash blended Portland cement. Indian J. Eng. Mater. Sci. 14: 69-76.

SINGH, N.B., DAS, S.S., SINGH, N.P. \& DWIVEDI, V.N. (2009). Studies on SCLA composite Portland cement. Indian J. Eng. Mater. Sci. 16: 415-422.

TEIXEIRA, S.R, SOUZA, A.E., CARVALHO, C.L, REYNOSO, V.C.S., ROMERO, M. \& RINCÓN, J.M. (2014). Characterization of a wollastonite glass-ceramic material prepared using sugar cane bagasse ash (SCBA) as one of the raw materials. Mater. Charact. 98: 209-214.

TUCK, O.C., PÉREZ, E., HORVÁTH, I.T., SHELDON, R.A. \& POLIAKOFF, M. (2012).Valorization of biomass: deriving more value from waste. Science 237: 695-699.

VILLAR-COCIÑA, E., MORALES, E.V., SANTOS, S.F., SAVASTANO, Jr. H. \& FRÍAS, M. (2011). Pozzolanic behavior of bamboo leaf ash: Characterization and determination of the kinetic parameters. Cem. Concr. Comp. 33: $68-73$. 
